ELORE (ISSN 1456-3010), vol. 19 - 1/2012.

Julkaisija: Suomen Kansantietouden Tutkijain Seura ry.

[http://www.elore.fi/arkisto/1_12/opas.pdf]

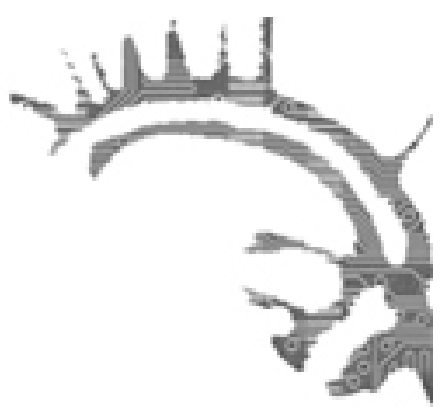

KIRJA-ARVIO

\title{
KULTTUURISISTA OLEMASSAOLON TAVOISTA INDONESIASSA
}

KAARTINEN, TIMO 2010: Songs of Travel, Stories of Place. Poetics of Absence in an Eastern Indonesian Society. Folklore Fellows Communications 299. Helsinki: Suomalainen Tiedeakatemia. 207 sivua.

\section{Minna Opas}

Historian, myyttien (tai perinteen) ja muistin välinen suhde on viime vuosina jälleen noussut yhdeksi keskeiseksi kiinnostuksen kohteeksi kulttuurientutkimuksessa. Miten muisti ja toisaalta unohtaminen limittyvät käsityksiin historiasta? Miten historia rakentuu osaksi perinnettä ja miten perinne puolestaan historioidaan? Erityisesti huomiota on kiinnitetty siihen, miten nämä muutokseen ja jatkuvuuteen keskeisesti liittyvät kategoriat ovat yhteydessä käsityksiin yksityisestä ja yhteisöllisestä identiteetistä. Jos muutos on identiteetin jatkuva olotila, miten ylipäätään saamme kiinni siitä identiteetistä, jota pyrimme tutkimaan?

Helsingin yliopiston sosiaali- ja kulttuuriantropologian professori Timo Kaartisen teos Songs of Travel, Stories of Place osallistuu näihin keskusteluihin. Teos liikkuu antropologian, folkloristiikan ja historiantutkimuksen kysymyksenasettelujen rajapinnoilla, ja sen pyrkimyksenä on ymmärtää kulttuurisen erityisyyden ja historiallisen muutoksen välistä suhdetta Indonesiassa. Kirjoittaja pyrkii valottamaan erityisesti sellaisia prosesseja, joissa henkilökohtaista elettyä kokemusta käytetään historian rakennusaineena ja joiden kautta toimijuutta tuotetaan historiallisten tapahtumien 
marginaalissa. Keskeiselle sijalle tässä tarkastelussa nousee suullinen perinne, laulut, kirjoitetut kertomukset ja puhumisen tavat ja konventiot. Omat huomioni teoksesta kumpuavat uskontoantropologisesta kiinnostuksestani erityisesti subjektiviteetin muodostumista mutta myös modernisaation prosessien ymmärtämistä kohtaan.

\section{BANDA-SAARTEN KONTEKSTI}

Kaartisen teos pohjautuu hänen väitöskirjaansa ja kenttätöihinsä Banda Elin kylässä Kei-saarilla Itä-Indonesiassa. Banda Eli ja samalla saarella sijaitseva Banda Elatin kylä ovat erityisiä, sillä ne ovat ainoita paikkoja, joissa edelleen puhutaan vanhaa, Bandasaarilta juontuvaa kieltä. Banda-saaret muodostivat erityisesti muskottipähkinän tuotannosta kuuluisan maustesaariryhmän ja kaupankäynnin keskuksen, jonka Dutch East India Company valloitti vuonna 1621 sillä seurauksella, että paikallisväestön oli paettava saarilta. Kaartisen teos osoittaa, kuinka bandaeliläisten muistot varhaisista vesiteitse tehdyistä kauppamatkoista ja pakolaisuudesta sekä nykypäivän tavat ja syyt matkustaa kauas toimivat toistensa vaikuttimina ja uusintavat diasporista kulttuurisen olemassaolon tapaa. Yhteys menneeseen ei Kaartisen mukaan säilynyt samanlaisena Banda-saarilta lähteneiden keskuudessa paikoissa, jotka olivat kielellisesti ja sosiaalisesti lähellä muuttajia. Banda Elissä bandalaisten jälkeläiset puolestaan ovat eläneet vieraan kulttuurin ympäröiminä ja ovat näin ollen vankemmin säilyttäneet ja luoneet uudelleen kulttuurista erityisyyttään. Samankaltaisia prosesseja voidaan havaita tänäkin päivänä esimerkiksi nykypäivän diasporassa elävien muslimien keskuudessa.

\section{MODERNISAATIOTUTKIMUKSEN KRITIIKKIÄ}

Metatasolla Kaartisen teos on kriittinen puheenvuoro modernisaatiotutkimuksen (paikallis-)historiaa ja yleisemmin toiseuden esittämistä ja analysointia koskeviin keskusteluihin. Kirjoittaja pyrkii eroon modernin ajattelun ilmiöitä jähmettävästä ja olemuksellistavasta vaikutuksesta ja näkee monien ilmiöiksi määriteltyjen kokonaisuuksien - tässä tapauksessa erityisesti subjektiviteetin - pikemminkin muodostuvan dialogisesti erilaisissa historian kertomisen ja muistamisen prosesseissa. Analyyttisenä työkaluna tämän dialogisuuden tarkastelussa hän käyttää sisä- ja ulkopuolen välistä kategorista erottelua. Tämä tulee erityisen näkyväksi bandaeliläisen suullisen perinteen keskeisissä teemoissa, joita Kaartinen kutsuu paikkakertomuksiksi (stories of place) ja matkalauluiksi (songs of trave). Paikkakertomukset viittaavat myytteihin, lauluihin ja paikannimiin, jotka vahvistavat perinteistä tai totuttua elämäntapaa. Matkalaulut puolestaan motivoivat ihmisten kiinnostusta ulkopuolisiin asioihin ja tapahtumiin.

Teos liikkuu kiinnostavasti eri teoreettisten perinteiden, tutkimuksellisten näkökulmien ja abstraktiotasojen välillä. Teoreettinen lähestymistapa on varsin hyvin toimiva yhdistelmä strukturalismia ja fenomenologiaa. Kirjan näkökulmat sekä käsitellyt teemat vaihtelevat yksittäisen toimijan sisäisestä kokemuksesta yhteisön jaettuun merkityk- 
senantoon, paikallishistoriasta globaalien poliittis-historiallisten tapahtumakulkujen ytimeen, kosmologiasta sosiaaliseen organisaatioon, paikasta aikaan ja suullisen perinteen genrestä toiseen. Tarkemmin sanottuna tarkastelun näkökulma keskittyy näiden ja useiden muiden ilmiö- ja käsiteparien rajapinnoille ja niiden risteyskohtiin. Keskittyminen ilmiöiden rajapinnoille tekee teoksesta lukijalle haastavan, sillä lähestymiskulmien moninaisuuden keskellä teoksen punaista lankaa on välillä vaikea seurata. Metsää ei tahdo nähdä puilta. Toisaalta tämä kertoo kenties enemmän siitä Kaartisen kritisoimasta käsitteellisestä jähmeydestä, josta käsin luen tekstiä länsimaisen modernin kategorisaatiotavan omaksuneena, ja vähemmän kirjoittajan ongelmista sovittaa yhteen moninaiset katsantokannat ja tutkimuskysymykset.

\section{SubJEKTIVITEETTI JA DIALOGI}

Keskeinen teema teoksessa on subjektiviteetin muodostuminen ja paikantuminen. Kaartinen pyrkii purkamaan asetelmaa, jossa subjektiviteetti ymmärretään vain yksilön ominaisuudeksi, joka välttämättä muuttuu globaalien virtausten saavuttaessa paikallistason. Yksi teoksen keskeisistä argumenteista on, että bandaeliläiset suullisen perinteen lajit ovat välineitä, joiden avulla ihmiset voivat ottaa osaa ja kotouttaa ulkopuolisten toisten diskursseja ja representaatioita ilman, että niistä tulee perusta heidän itsemäärittelylleen. Erityisesti matkalaulujen kaksi genreä, onotani- ja singnyat-laulut, ovat tässä suhteessa Kaartisen mukaan keskeisiä. Nämä laulut kertovat bandaeliläisten menneistä merimatkoista kaukaisille maille. Laulujen matkaajien kautta ihmiset sijoittavat itsenä osaksi globaalia historiaa, mutta korostamalla matkaajien etäisyyttä nykyhetkeen he samalla ylläpitävät omaa kulttuurista erityisyyttään. Kaartisen näkemys matkalauluista pohjautuu Roy Wagnerin ajatukseen invention ja konvention välisestä suhteesta. Matkalauluille, samoin kuin muulle bandaeliläiselle suulliselle perinteelle annetut merkitykset riippuvat Kaartisen mukaan siitä dialogisesta tavasta, jolla niiden sisältämä vuoropuhelu viimeistellään suhteessa tiettyyn yleisöön tai kuulijakuntaan. Subjektiviteetti muotoutuu näiden laulujen kontekstissa moninkertaisissa eri paikkoihin ja aikoihin liittyvissä dialogisissa suhteissa.

Vaikka se muoto, jonka subjektiviteetin dialoginen rakentuminen bandaeliläisten keskuudessa saa, onkin omaleimainen, liittyy itse ajatus subjektiviteetin ja subjektin dialogisuudesta vahvasti viime vuosikymmeninä käytyihin sosiaalitieteellisiin keskusteluihin itsen, persoonan ja subjektiviteetin rakentumisesta. Siksi onkin kiinnostavaa ja kysymyksiä herättävää, että Kaartinen ei suoraan teoksessaan osallistu tai viittaa näihin keskusteluihin, etenkin kun yhtymäkohdat esimerkiksi Marilyn Strathernin (1988) individual-dividual-jaotteluun ovat ilmeiset. Itse näen Kaartisen analyysissa yhtymäkohtia myös amerindiseen näkemykseen subjektiviteetin rakentumisesta, joskin tuossa kulttuurisessa kontekstissa suullisen perinteen sijaan pääpaino on ruumiillisuudessa (esim. Conklin 1996; Vilaça 2002). 


\section{LUKUKOKEMUKSESTA}

Nämä lyhyet huomiot eivät tee oikeutta Kaartisen teokselle, josta riittäisi ammennettavaa useammalle kuin yhdelle lukukerralle. Teos käsittelee ansiokkaasti useita kulttuuritutkimukselle keskeisiä teemoja, joista yllä käsittelin vain subjektiviteetin muodostumista sekä perinteen ja muutoksen välistä suhdetta. Oman käsittelynsä olisivat ansainneet myös esimerkiksi muisti, historia, toimijuus, performatiivisuus, suullisen perinteen lajit, lingvistinen ideologia, tila ja liike sekä rituaalit vain muutamia teemoja mainitakseni. Myös strukturalismin ja fenomenologian yhdistäminen tutkimusotteessa kutsuu lähempään tarkasteluun.

Kaartisen työ on pitkän tutkimus- ja kirjoitusprosessin tulos, mikä näkyy erityisesti kirjoittajan teoreettisessa otteessa. Kenties olisinkin kaivannut työhön ajoittain vastapainoksi laajempaa etnografista kuvausta, jonka avulla olisi saanut tuntumaa siihen arkitodellisuuteen, johon suullinen perinne Banda Elillä nivoutuu. Esimerkiksi bandaeliläisiin muslimeina lukija pääsee tutustumaan vasta kirjan loppupuolella, mikä jättää tämän puolen heidän kulttuurisesta kokemusmaailmastaan lukijalle varsin irralliseksi.

Kokonaisuutena Kaartisen kirjan modernisaatiokriittinen ote luo mahdollisuuden tarkastella ilmiöitä länsimaisen modernin luomien rakenteiden ohi. Erityisesti Kaartinen nostaa keskiöön käsiteparit muisti ja subjektiviteetti sekä historia ja valtio ja katsoo modernisaatiotutkimuksen tuottavan näiden kautta vääristynyttä kuvaa yksilöstä ainoana paikkana, johon inhimillinen merkityksellinen kokemus voi kiinnittyä. Kaartisen teos osoittaa, että ihmisyys, subjektiviteetti, toimijuus ja itse eivät käsitteinä ole yhteismitallisia modernin rajatun yksilön käsitteen kanssa vaan laajentavat sitä sekä laajenevat kullekin kulttuuriperinteelle ominaisella tavalla intersubjektiiviseen tilaan ja aikaan. Kaartisen teos on ajatuksia herättävää luettavaa kaikille näiden kysymysten parissa kulttuurintutkimuksen laajalla kentällä työskenteleville.

\section{LÄHTEET}

CONKLIN, BETH A. 1996: Reflections on Amazonian Anthropologies of the Body. - Medical Anthropology Quarterly 10(3).

STRATHERN, MARILYN 1988: The Gender of the Gift. Berkeley: University of California Press.

VILAÇA, APARECIDA 2002: Making Kin Out of Others in Amazonia. - Journal of the Royal Anthropological Institute 8.

Filosofian tohtori Minna Opas toimii Suomen Akatemian tutkijatohtorina Turun yliopiston uskontotieteen oppiaineessa. 